\title{
Women Entrepreneur in Micro, Small and Medium Enterprises in India - An Overview
}

\author{
*Dr. Rashmi
}

\begin{abstract}
In the present article, role of women entrepreneurs in micro, small and medium enterprises are discussed. Problems faced by women entrepreneurs are highlighted. Schemes introduced by government to promote women entrepreneurs are mentioned and finally certain suggestions are provided to encourage them.
\end{abstract}

Keywords: women entrepreneurs, micro, small and medium enterprises.

\section{Women EnTrepreneur in Micro, SMALl ANd Medium EnTERPrises IN INDiA - AN OVERVIEW}

Women entrepreneur may be defined as the woman or a group of women, who initiate, organise and operate a business enterprise. Government of India has defined women entrepreneur as an enterprise owned and controlled by a women having a minimum financial interest of $51 \%$ of capital and giving at least $51 \%$ of employment generated in the enterprise to women.

"Success after comes to those who have the aptitude to see way down the Road". Relying on the same, Indian women have covered a long way and are becoming increasingly visible and successful in all spheres. In India, women constitute around 48 percent of the population but their participation in the economic activities is only 34 percent. Since the turn of the century, the status of the women in India has been changing due to the growing industrialisation, urbanisation, spatial mobility and social legislation. With the spread of education and awareness, the traditional roles of housewives are gradually changing into women entrepreneurs.

In this male dominating society, starting an enterprise is not an easy task especially for women entrepreneurs. In such a situation, more and more women are starting their entrepreneurial role through micro, small and medium enterprises (MSMEs). In India, MSMEs play an important role in the overall economic development of the country. This sector contributes about 8 percent of the GDP of India, 45 percent of the manufactured output and 40 percent of the exports. They provide employment to over 60 million persons through more than 26 million enterprises (Kushalakshi and Raghurama, 2014).

\section{Micro, SMall ANd Medium ENTERPriSES - Definition}

Micro, small and medium enterprises development (MSMED) Act 2006 has classified these enterprises into categories.

In case of manufacturing sector for investment in plant and machinery

Micro enterprises does not exceed twenty five lakh rupees

Small enterprises more than twenty five lakh rupees but does not exceed five crore rupees

Medium enterprises more than five crore rupees but does not exceed ten crore rupees

In case of service sector for investment in equipments

Micro enterprises does not exceed ten lakh rupees

Small enterprises more than ten lakh rupees but does not exceed two crore rupees

Medium enterprises more than two crore rupees but does not exceed five crore rupees

\section{Problems of Women EnTrepreneurs in India}

The status of women suffered a lot of problems in earlier times. She was engaged in various social evils such as the ritual of sati, jauhar (mass suicide), child marriage, restriction on widow remarriage, 
purdah system, devadasis (servant of God). Though, presently she has come out of these evils, still it is understood that her role is confined to building and maintaining of homely affairs like task of fetching water, cooking and rearing children. Though woman has proved herself in this male directing world but still she suffers a lot of problems which are discussed as under:

Male Dominating Society: The main problem to women entrepreneurs is that they are women. A male dominant social order is the building block to them in their way towards business success. Male members think it a big risk financing the ventures run by women.

Family Obligations: Women's family obligations also bar them from becoming successful entrepreneurs in both developed and developing nations. "Having primary responsibility for children, home and older dependent family members, few women can devote all their time and energies to their business." The financial institutions discourage women entrepreneurs on the belief that they can at any time leave their business and become housewives again. The result is that they are forced to rely on their own savings, and loan from relatives and family friends.

Marketing: The other hand women face marketing challenges in the form of competition from cheaper and substitute product, delayed payment and liberal credit terms. Women entrepreneurs neither have knowledge nor access to proper market, thus they sell their product through the middle man. This middle man exploits them and entrepreneur received for price than desired even if the demand of product is high.

Finance: Finance is a critical resource for venture creation. It is very important that women entrepreneurs have adequate knowledge and information of the various financial institutions which are rendering financial incentives and many other help for the women entrepreneurs in the region. Women entrepreneurs are not able to have access for external finance. An important reason that makes banks reluctant to provide loans is the inability of the women entrepreneurs to provide collaterals. The complicated procedure of bank loans also creates lot of problems in getting the required finance. Obtaining the support of bankers, lack of credit resources and managing the working capital are the problems that still remain in the males' domain.

Management Problem: It is normally believed that women have low managerial skill. But in fact women are stronger in more logic based skills though they are weaker in self promotion and handling frustration. The increasing number of female students and their excellent performance in management education is a proof to the fact.

Mobility Constraints: Women in India have got restricted mobility, our society is a conservative society, and the career of women was limited to four walls of kitchen. Although now, women have got relatively more freedom in terms of entrepreneurial activity but also by the family members if they move out after normal hours. Though women faced lots of problems being mobile in entrepreneurial activity, the mobility problem has been solved to certain extent by the expansion of education awareness to all. DUAL Dual responsibility: The most exploited individual of the day are the working women, as they have to perform dual responsibility, one at work and another as family as mother of wife. The level of women exploitation on family responsibility ground depends on her social dependence.

Risk-Bearing Ability: One pre-requisites of the entrepreneurial success is risk taking. It is normally believe that women being feminist gender have low risk taking ability. They are being suppressed by the protected environment and are not allowed most of the time to take any type of risk even if she is willing or she has the ability to bear.

Scarcity of Raw Materials: The scarcity of required raw materials is the major problem faced by women entrepreneurs. They find it difficult to procure the required raw materials and other essential inputs for production in sufficient quantity and quality, because the prices of raw materials are quite high and fluctuate.

In addition to the above problems, high cost of production, inadequate power supply, non-availability of labour, lack of self-confidence and socio-economic constraints hold the women back from entering into business.

\section{SCHEMES FOR WOMEN ENTREPRENEURS}

At present, the Government of India has over 27 schemes for women operated by different departments and ministries. Some of these are: 
1. Integrated Rural Development Programme (IRDP)

2. Khadi and Village Industries Commission (KVIC)

3. Training of Rural Youth for Self-Employment (TRYSEM)

4. Prime Minister's Rojgar Yojana (PMRY)

5. Entrepreneurial Development programme (EDPs)

6. Management Development progammes

7. Women's Development Corporations (WDCs)

8. Marketing of Non-Farm Products of Rural Women (MAHIMA)

9. Assistance to Rural Women in Non-Farm Development (ARWIND) schemes

10. Trade Related Entrepreneurship Assistance and Development (TREAD)

11. Working Women's Forum

12. Indira Mahila Yojana

13. Indira Mahila Kendra

14. Mahila Samiti Yojana

15. Mahila Vikas Nidhi

16. Micro Credit Scheme

17. Rashtriya Mahila Kosh

18. SIDBI's Mahila Udyam Nidhi

19. Mahila Vikas Nidhi

20. SBI's Stree Shakti Scheme

21. NGO's Credit Schemes

22. Micro \& Small Enterprises Cluster Development Programmes (MSE-CDP).

23. National Banks for Agriculture and Rural Development's Schemes

24. Rajiv Gandhi Mahila Vikas Pariyojana (RGMVP)

25. Priyadarshini Project- A programme for Rural Women Empowerment and Livelihood in Mid Gangetic Plains,

26. NABARD- KfW-SEWA Bank project

27. Exhibitions for women, under promotional package for Micro \& Small enterprises approved by CCEA under marketing support

\section{WOMEN ENTREPRENEUR ASSOCIATIONS}

The efforts of government and its different agencies are supplemented by NGOs and associations that are playing an equally important role in facilitating women empowerment. List of various women associations in India is provided below.

1. Federation of Indian Women Entrepreneurs (FIWE)

2. Consortium of Women Entrepreneurs(CWEI)

3. Association of Lady Entrepreneurs of Andhra Pradesh

4. Association of Women Entrepreneurs of Karnataka (AWAKE)

5. Self-Employed Women's Association (SEWA)

6. Women Entrepreneurs Promotion Association (WEPA)

7. The Marketing Organisation of Women Enterprises (MOOWES) 
8. Bihar Mahila Udyog SanghBihar Mahila Udyog Sangh

9. Mahakaushal Association of Woman Entrepreneurs (MAWE)

10. SAARC Chamber Women Entrepreneurship Council

11. Women Entrepreneurs Association of Tamil Nadu (WEAT)

12. Tie Stree Shakti (TSS)

13. Women Empowerment Corporation

\section{Key Policy Recommendations}

Increase the ability of women to participate in the labour force by ensuring the availability of affordable child care and equal treatment in the work place. More generally, improving the position of women in society and promoting entrepreneurship generally will have benefits in terms of women's entrepreneurship.

Listen to the Voice of Women Entrepreneurs. The creation of government offices of women's business ownership is one way to facilitate this. Such offices could have programme responsibilities such as providing women's business centres, organising information seminars and meetings and/or providing web-based information to those wanting to start and grow a business.

Incorporate a women's entrepreneurial dimension in the formation of all SME-related policies. This can be done by ensuring that the impact on women's entrepreneurship is taken into account at the design stage.

Promote the development of women entrepreneur networks. These are major sources of knowledge about women's entrepreneurship and valuable tools for its development and promotion. Co-operation and partnerships between national and international networks can facilitate entrepreneurial endeavours by women in a global economy.

Periodically evaluate the impact of any SME-related policies on the success of women-owned businesses and the extent to which such businesses take advantage of them. The objective should be to identify ways to improve the effectiveness of those that should be retained. Good practices that are identified in this way should be disseminated and shared internationally.

Improve the factual and analytical underpinnings of our understanding of the role of women entrepreneurs in the economy. This requires strengthening the statistical basis for carrying out gender-related cross-country comparative analyses and longitudinal studies of the impact of important developments and policies, especially over time.

Tax advantage. In the previous financial years, woman was enjoying more exemption limit as compared to males. However in the tax slabs of FY 2013-14, male and female has no dicrimation in exemption limit. It discourages woman. Woman should be given more tax advantage in comparison of males.

\section{CONCLUSION}

As compared with past, women in modern times have achieved a lot but in reality they have to still travel a long way. Their path is full of roadblocks. Though women of India are not at par with her counterpart in Western world but she is struggling hand to mark her presence in men's world.

\section{REFERENCES}

Annual Report (2012-13), Mininstry of Micro, Small and Medium Enterprises Government of India.

Kushalakshi and Raghurama, A. (2014), "Problems of Women Entrepreneurs of Micro, Small, and Medium Enterprises (MSMEs)", Global Journal for Research Analysis, Vol. 3 No. 1, pp. 9,10.

Pazir, D. and Hussain, S. (2012), "Womens participation in Micro, Small and Medium Enterprises", Zenith International Journal of Business Economics and Management Research, Vol. 2, No. 3, pp. 183-194.

Vijaykumar, T. and Naresh, B. (2013), "Women Entrepreneurship in India - Role of Women in Small and Medium Enterprises", Trans Asian Journal of Marketing and Management Research, Vol. 2, No. 7, pp. 13-25. 


\section{AUTHOR'S BIOGRAPHY}

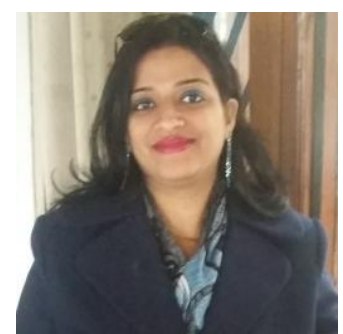

Dr. Rashmi (M.Com, PhD), is working as an Assistant Professor in D.A.V. College, Bathinda. Her one book titled Consumer Choice Process: An Empirical Study of Indian Consumers is released. Her twenty articles have been published in various national and international journals. She has participated in two national conferences and also one paper has been presented at an international conference. She has two years and eight months of research experience and four years of teaching experience. She has acted as a reviewer for various journals as well as she is editorial board member of SOP transactions on Marketing Research, Global Research Journal of Business Management, Global Research Journal of Marketing Management, Blue Ocean Research Journal. 